Preface

Women Entrepreneurs in Asia: Eight Country Studies

Issue Editors:

Yonjoo $\mathrm{Cho}^{1}$

Indiana University

Jessica Li

University of Illinois at Urbana-Champaign

Sanghamitra Chaudhuri

University of Minnesota

${ }^{1}$ Corresponding editor at choyonj@indiana.edu 


\section{Women Entrepreneurs in Asia: Eight Country Studies}

As the book titled The Future is Asian (Khanna, 2019) indicates, Asia is the fastestgrowing region in the world in terms of productivity, investment, technology, and innovation. However, gender inequality and underutilization of female talent are deeply rooted and widely spread in Asian countries (McKinsey Global Institute, 2018). The World Economic Forum's (2018) gender gap report ranked China $103^{\text {rd }}$, India $108^{\text {th }}$, Indonesia $85^{\text {th }}$, Japan $110^{\text {th }}$, South Korea (Korea) $115^{\text {th }}$, Malaysia $101^{\text {st }}$, Thailand $73^{\text {rd }}$, and Vietnam $77^{\text {th }}$ out of 149 countries in the combined evaluation of economic participation, educational attainment, health and survival, and political empowerment in terms of women's status compared with that of male counterparts. Asia's gender gap index is alarming because almost all countries, except the Philippines $\left(8^{\text {th }}\right)$, occupy low rankings in women's status, despite the region's rapid economic development potential.

\section{Asian Context}

Asia as a research context (Barkema, Chen, George, Luo, \& Tsui, 2015) is significantly different, in many ways, from western contexts where a majority of studies on women in leadership have been conducted (Badura, Grijalva, Newman, Yan, \& Jeon, 2018; Joshi, Neely, Emrich, Griffiths, \& George, 2015; Madsen \& Scribner, 2017). First, traditional culture (e.g., Confucianism) and religious beliefs (e.g., Hinduism) in Asia dictate the inferior status of women in their daily lives. Second, women's appointment to high-ranking leadership roles in Asia has been a continuing challenge. Third, many organizations in Asia remain as gendered workplaces where cultural, religious, and organizational constraints coexist. This special issue on women entrepreneurs in Asia, therefore, will make specific contributions to research on Asian women in leadership in the context of entrepreneurship. 
According to McKinsey Global Institute's (2018) report on women's equality in Asia, the region can benefit greatly by advancing women's participation in economic activities in enhancing its economic development. Although there has been a noticeable increase in women entrepreneurs, there is an urgent need to develop and promote women entrepreneurs for sustainable economic growth in Asia (Global Entrepreneurship Monitor, 2018; Mastercard, 2018). In Korea, for instance, there are approximately 3,300 venture companies owned by women, which is only $10 \%$ of all venture companies (personal communication with HS Kim, Managing Director of the Korea Venture Business Women’s Association, July 11, 2018). In India, $45 \%$ of the venture companies are owned by women, which calls for effective training and skill development to bolster entrepreneurial awareness (Gali, 2016). In China, women make up only $20 \%$ of total entrepreneurs (Wang, 2011).

Women entrepreneurs in general face challenges as business owners to survive in fiercely competitive domestic and global markets and as women to strike a balance between work and life (Bullough, \& Renko, 2017). Despite challenges and difficulties that women entrepreneurs face, the opportunities that they create can serve as a model for aspiring women entrepreneurs in Asia and other countries. In this context, the purpose of this special issue is to investigate women entrepreneurs' motivations, challenges, and opportunities in eight Asian countries, develop evidence-based strategies for organizations and governments to devise policies and programs to support the development of women entrepreneurs, and provide implications for HRD research and practice.

\section{Conceptual Background}

Critical to this special issue on women entrepreneurs in Asia is an understanding of the conceptual background of definitions and motivational factors. This theoretical background helps 
us understand different types of women entrepreneurs in Asia including: women CEOs in startups and small and medium-sized enterprises (SMEs) (Korea), second-generation women successors in family-owned businesses (China), urban women entrepreneurs (India), women social entrepreneurs (Japan), and innovative women entrepreneurs (Thailand) and their motivations to create, own, and/or manage businesses.

\section{Definition}

Entrepreneurship refers to the identification, evaluation, and exploitation of new business opportunities (Shane \& Venkataraman, 2000). When it comes to the local words for entrepreneurs in rapidly emerging countries, siying qiye zhu in China, vaishyas in India, and Chang-Up-Ga in Korea, for instance, are not necessarily favorable to entrepreneurs (Gupta, Guo, Canever, Yim, Sraw, \& Liu, 2014). Despite the differences in defining entrepreneurs, entrepreneurship research emphasizes aspects of risk-taking and innovation in business creation and development. The Organisation for Economic Co-operation and Development (OECD), for instance, defined entrepreneurs as "those (business owners) who seek to generate value, through the creation or expansion of economic activity, by identifying and exploiting new products, processes, or markets" (Ahmad \& Seymour, 2008, p. 14). Later, the OECD added those who are self-employed for earning a profit in their original definition (OECD, 2010). We, therefore, define entrepreneurs as those who start, own, and/or manage startups and SMEs on products, processes, or markets with innovation and risk-taking.

Research (Carter, Shaw, Lam, \& Wilson, 2007; Shane, 2008) indicates that gender is an important factor that affects motivation for business start-ups and types of challenges that entrepreneurs face, and, therefore, conceptualized women entrepreneurs from a different perspective than man entrepreneurs: motherhood and social norms such as gender roles were 
important factors in understanding women's entrepreneurship (Brush, de Bruin, \& Welter, 2009).

Entrepreneurship, therefore, is a gendered phenomenon and entrepreneurial activities occur within systems of socially constructed and shared beliefs about gender, which affect women entrepreneurs' motivations for business creation and development and types of challenges that they face (Jennings \& Brush, 2013; Henry, Foss, \& Ahl, 2017).

\section{Motivational Factors}

Motivational factors influence women entrepreneurs to create, own, and/or run businesses with innovative mindsets, and are divided into necessity-based push and opportunity-based pull factors (Jennings \& Brush 2013).

Push factors. Push factors force women to give up their current work due to their family's economic needs, gender inequality, and work and family conflict (Zgheib, 2018). Women entrepreneurs are more likely to be motivated by push factors than men (Jennings \& Brush, 2013). The need for increasing family income motivates women to start a business, while men's entrepreneurial intention was not influenced by the family income factor (Allen \& Curington, 2014). Gender inequality increases the necessity of women to quit their jobs and to choose self-employment (Reavley \& Lituchy, 2008). Women's career opportunities are often hindered by marriage, childcare, and the glass ceiling, which lead women to leave their jobs and start a business (Zgheib, 2018). Women who pursue a balance between work and family tend to choose self-employment to reduce work and family conflict (Agarwal \& Lenka, 2015).

Pull factors. Pull factors attract women into entrepreneurship and influence decisions on self-employment: a desire for career advancement, a need for independence, self-efficacy, and family background (Zgheib, 2018). A desire for career advancement is an important motivational factor for women's business ownership across cultures (Tan, 2008). Many women are motivated 
to become entrepreneurs in pursuing independence (Alam, Senik, \& Jani, 2012). Women entrepreneurs' self-efficacy is considered a significant predictor of women's entrepreneurial intentions that are more affected by self-efficacy than men (Shinnar, Hsu, \& Powell, 2014). Entrepreneurial self-efficacy increased when women were exposed to entrepreneurial role models (Austin \& Nauta, 2016). Women who have a family business tradition (e.g., fathers or husbands) are more likely to start a business than women without such a family background (Sasu \& Sasu, 2015).

\section{Purpose of the Special Issue}

The purpose of this special issue is to examine women entrepreneurs' motivations, challenges, and opportunities in business creation and development. Initially we chose seven Asian countries (China, India, Indonesia, Japan, Korea, Malaysia, and Thailand) based on our previous research collaboration on a book titled Current Perspectives on Asian Women in Leadership (Cho, Ghosh, Sun, \& McLean, 2017) and added Vietnam due to its recent noticeable economic development and strong presence of entrepreneurs in the country (Global Entrepreneurship Monitor, 2018).

To lead the development of this special issue, we asked three broad research questions to all participating authors: What motivated women entrepreneurs to start/own/manage a business? What challenges did they face in their business development? What opportunities contributed to their business success? These three questions are broad enough so that authors can address country- specific questions that are relevant to their unique cultural context including: "Why do women enter into entrepreneurship in Korea", "How do mentoring programs help women become entrepreneurs in India?", "Who are innovative women entrepreneurs in Thailand?", and "Why are women social entrepreneurs increasing in number in Japan?" 
As women entrepreneurs' challenges are of global interest, this special issue will represent an effort to transcend national boundaries in understanding how to address those challenges they face. Scholars and practitioners who are interested in international human resource development (HRD) can better understand how Asia's fast-growing economies and culture have influenced women entrepreneurs in positive and negative ways. And we will provide insights into developing the potential of aspiring women entrepreneurs who are set in rapidly developing Asian countries where traditional cultural and religious expectations and modernized values coexist.

\section{Table of Contents}

Following are the titles and authors of eight country articles as well as preface and closing chapters (in alphabetical order of the country names):

- Preface Women entrepreneurs in Asia: Eight country studies (Yonjoo Cho, Jessica Li, \& Sanghamitra Chaudhuri)

- Article 2: The development of the second-generation women successors in Chinese family-owned businesses (Jessica Li, Judy Sun, Lianjuan Wang, \& Jie Ke)

- Article 3: Exploring the risky terrain of entrepreneurship with the help of mentors: Narratives from Indian women entrepreneurs (Sanghamitra Chaudhuri, Rajashi Ghosh, \& Yogita Abichandani)

- Article 4: Developing women entrepreneurs in Indonesia: The role of motives, identity conflict, and time orientation (Corina Riantoputra \& Ismarli Muis)

- Article 5: Transformative learning in crisis: A framework for developing women social entrepreneurs in Japan (Yoshie Tomozumi Nakamura \& Mayuko Horimoto) 
- Article 6: What makes South Korean women entrepreneurs start and sustain the development of their businesses? (Yonjoo Cho, Jiwon Park, Soo Jeoung Han, \& Hyounju Kang)

- Article 7: Exploring Malaysian women entrepreneurs' development of self-leadership (Roziah Mohd Rasdi, Siti Raba'ah Hamzah, \& Tan Fee Yean)

- Article 8: Vicarious learning from life stories of innovative women entrepreneurship in Thailand (Dawisa Sritanyarat \& Malinvisa Sakdiyakorn)

- Article 9: Women entrepreneurs in Vietnam: Motives, challenges, and successes (Hoang Anh Nguyen)

- Closing Article: Learning from the diversity and opportunities of women entrepreneurs in Asia (Yonjoo Cho, Jessica Li, \& Sanghamitra Chaudhuri)

\section{Overview of the Issue}

Women entrepreneurship in Asia is certainly gaining traction as entrepreneurship development is directly related to a country's economic development, transformational changes to society, and, most importantly, women empowerment. Women entrepreneurship development presents women entrepreneurs with opportunities to not only participate in economic activities but also help alleviate overall poverty (Tambunan, 2009). In this special issue, we bring forward the stories of women entrepreneurs from eight Asian countries that are intertwined with HRD themes.

The purpose of the Preface is to revisit the definition of women entrepreneurs in Asian contexts. Preface acts as a conduit connecting the different countries to entrepreneurial motivations, challenges, and opportunities and highlights how women entrepreneurs have paved the way to build HRD capacities at individual, organizational, and country levels. 
Article 2 provides a unique perspective of the challenges the second-generation women successors face in Chinese family-owned businesses. Through in-depth qualitative interviews, this chapter delineates the contribution of HRD toward the development of the second-generation women successors in management, leadership, and entrepreneurship.

Article 3 tells rich stories from urban women entrepreneurs in India through interviews on the importance of multiple developmental relationships and how those contributed to their career success. The study contributes to the presentation of the critical ingredients needed to develop formal mentoring programs for women employees who leave the safe haven of corporate India to start their own entrepreneurial ventures.

Article 4 investigates the various factors that influence the behaviors of necessity- and growth-oriented women entrepreneurs in Indonesia. The study findings will be informative to policy makers and HRD in organizations in creating coaching and developmental strategies for women entrepreneurs.

Article 5 explores the connection between women social entrepreneurship, authentic entrepreneurial leadership, and transformative learning theories in a Japanese context through an extensive literature review and concludes with HRD implications for women social entrepreneurship development.

Article 6 offers a case study of four women entrepreneurs in Korea who represent those who started their businesses on the basis of push and pull factors. Using a corporate life cycle (startup, growth, maturity, revival, and decline) (Miller \& Friesen, 1984), the case study investigates what motivated women entrepreneurs to start a business, what challenges they faced, and what opportunities they created for success. The findings of this study provide 
recommendations for the government and HRD to create a system to support the development of aspiring women entrepreneurs.

Article 7 promotes the development of self-leadership skills for Malaysian women entrepreneurs and describes how HRD interventions (e.g., training, mentoring, and role modeling) play an important role in nurturing them.

Using a phenomenological approach, Article 8 highlights the lived experiences of opportunity-driven, innovative Thai women entrepreneurs and the challenges they face as they engage in changing Thai values and culture regarding gender roles and social norms that depart from the past. The study concludes with a learning and development framework for facilitating and preparing innovative women entrepreneurs.

Article 9 shows that despite a higher level (31.3\%) of Vietnamese women's ownership in the economy (Mastercard, 2018), they have faced significant challenges including a widening gender gap, income gaps, and work-life imbalance. Six women entrepreneurs from different industries are interviewed to explore Vietnamese female entrepreneurs' lived experiences in motivations and challenges in their business creation. Understanding Vietnamese women entrepreneurship in this chapter provides implications for HRD from individual, organizational, and national perspectives.

The closing article discusses the diversity of the challenges and opportunities that we learn from the studies of eight Asian countries. Detailed descriptions of all chapters are summarized in the next section. 


\section{References}

Agarwal, S., \& Lenka, U. (2015). Study on work-life balance of women entrepreneurs - review and research agenda. Industrial \& Commercial Training, 47(7), 356-362.

Ahmad, N. \& Seymour, R. (2008). Defining entrepreneurial activity: Definitions supporting frameworks for data collection (Working Paper). Retrieved from https://doi.org/10.1787/243164686763

Alam, S. S., Senik, Z. C., \& Jani, F. M. (2012). An exploratory study of women entrepreneurs in Malaysia: Motivation and problems. Journal of Management Research, 4(4), 282-297.

Allen, W. D., \& Curington, W. P. (2014). The self-employment of men and women: What are their motivations? Journal of Labor Research, 35(2), 143-161.

Austin, M. J., \& Nauta, M. M. (2016). Entrepreneurial role-model exposure, self-efficacy, and women's entrepreneurial intentions. Journal of Career Development, 43(3), 260-272.

Badura, K. L., Grijalva, E., Newman, D. A., Yan, T. T., \& Jeon, G. (2018). Gender and leadership emergence: A meta-analysis and explanatory model. Personnel Psychology, $71,335-367$.

Barkema, H. G., Chen, X.-P., George, G., Luo, Y., \& Tsui, A. S. (2015). West meets East: New concepts and theories. Academy of Management Journal, 58(2), 460-479.

Bullough, A., \& Renko, M. (2017). A different frame of reference: Entrepreneurship and gender differences in the perception of danger. Academy of Management Discoveries, 3(1), 2141.

Bush, C. G., de Bruin, A., \& Welter, F. (2009). A gender-aware framework for women's entrepreneurship. International Journal of Gender and Entrepreneurship, 1(1), 8-24. 
Carter, S., Shaw, E., Lam, W., \& Wilson, F. (2007). Gender, entrepreneurship, and bank lending: The criteria and processes used by bank loan officers in assessing applications. Entrepreneurship Theory and Practice, 31(3), 427-444.

Cho, Y., Ghosh, R., Sun, J., \& McLean, G. N. (Eds.) (2017). Current perspectives on Asian women in leadership: A cross-cultural analysis. New York: Palgrave Macmillan.

Gali, R. M. (2016). Status of women entrepreneurship in India. International Journal of Multidisciplinary Educational Research, 5 (2), 206-217.

Global Entrepreneurship Monitor. (2018). 2017-2018 Global Report. Retrieved from https://www.gemconsortium.org/report

Gupta, V. K., Guo, C., Canever, M., Yim, H. R., Sraw, G. K., \& Liu, M. (2014). Institutional environment for entrepreneurship in rapidly emerging major economies: The case of Brazil, China, India, and Korea. International Entrepreneurship and Management Journal, 10, 367-384.

Henry, C., Foss, L., \& Ahl, H. (2016). Gender and entrepreneurship research: A review of methodological approaches. International Small Business Journal, 34(3), 217-241.

Jennings, J. E., \& Brush, C. G. (2013). Research on women entrepreneurs: Challenges to (and from) the broader entrepreneurship literature? The Academy of Management Annals, 7(1), 663-715.

Joshi, A., Neely, B., Emrich, C., Griffiths, D., \& George, G. (2015). Gender research in AMJ: An overview of five decades of empirical research and calls to action. Academy of Management Journal, 58(5), 1459-1475.

Khanna, P. (2019). The future is Asian: Commerce, conflict, and culture in the $21^{\text {st }}$ century. New York: Simon \& Schuster. 
Madsen, S. R., \& Scribner, R. T. (2017). A perspective on gender in management: The need for strategic cross-cultural scholarship on women in management and leadership. Cross Cultural \& Strategic Management, 24(2), 231-250.

Mastercard (2018). Mastercard Index of Women Entrepreneurs (MIWE) 2018 (Report). Retrieved from https://newsroom.mastercard.com/wpcontent/uploads/2018/03/MIWE_2018_Final_Report.pdf

McKinsey Global Institute. (2018). The power of parity: Advancing women's equality in Asia Pacific (Report). Available at: https://www.mckinsey.com/featured-insights/gender-equality/thepower-of-parity-advancing-womens-equality-in-asia-pacific

OECD (2010). Open for business: Migrant entrepreneurship in OECD countries. Retrieved from https://doi.org/10.1787/9789264095830-en

Reavley, M. A., \& Lituchy, T. R. (2008). Successful women entrepreneurs: A six-country analysis of self-reported determinants of success more than just dollars and cents. International Journal of Entrepreneurship and Small Business, 5(3-4), 272-296.

Sasu, C., \& Sasu, L. (2015). Demographic determinant of the entrepreneurship intentions. The case of Romania. Procedia Economics and Finance, 20, 580-585.

Shane, S. (2008). The illusions of entrepreneurship: The costly myths that entrepreneurs, investor, and policy makers live by. New Haven, CT: Yale University Press.

Shane, S., \& Venkataraman, S. (2000). The promise of entrepreneurship as a field of research. Academy of Management Review, 25(1), 217-226.

Shinnar, R. S., Hsu, D. K., \& Powell, B. C. (2014). Self-efficacy, entrepreneurial intentions, and gender: Assessing the impact of entrepreneurship education longitudinally. The International Journal of Management Education, 12(3), 561-570. SME Corporation 
Malaysia. (2016). Economic census 2016: Profile of SMEs. Available at http://www.smecorp.gov.my/index.php/en/policies/2015-12-21-09-09-49/sme-statistics

Tambunan, R. (2009). Women entrepreneurship in Asian developing countries: Their development and main constraints. Journal of Development and Agricultural Economics, 1(2), 027-040.

Tan, J. (2008). Breaking the "bamboo curtain" and the "glass ceiling": The experience of women entrepreneurs in high-tech industries in an emerging market. Journal of Business Ethics, $80(3), 547-564$.

Wang, F. (2011). Domestic research on women entrepreneurship: Present situation and prospect. Journal of China Women's University. 5(5), 49-55.

World Economic Forum (2018). The global gender gap report 2018. Retrieved from http://reports.weforum.org/global-gender-gap-report-2018/

Zgheib, P. (2018). Multi-level framework of push-pull entrepreneurship: Comparing American and Lebanese women. International Journal of Entrepreneurial Behavior and Research, 24(3), 768-786. 


\section{Author Bios}

Sanghamitra Chaudhuri (chaud020@umn.edu) is a Lecturer of Organizational Leadership, Policy, and Development in the College of Education and Human Development and is a co-chair of the Women Executive Leadership Series at the University of Minnesota. She serves on the Editorial Board of the Human Resource Development Review and Sage Open. She is the chair of the India HRD SIG of the AHRD.

Yonjoo Cho (choyonj@indiana.edu) is an associate professor of Instructional Systems Technology focusing on HRD at Indiana University. Before joining IU, she worked in for-profit, non-profit-, and academic sectors in South Korea. Her research interests include action learning, HRD, and women in leadership. She serves as an associate editor of the Human Resource Development Review and is a board member of the AHRD and the Korean Action Learning Association. She received her Ph.D. in instructional technology from the University of Texas at Austin.

Jessica Li (jli2011@illinois.edu, 217.333.0807) is the Editor-in-Chief of Human Resource Development International and a regional editor for the Journal of Chinese Human Resource Management. Dr. Li is currently an associate professor and program director of HRD at the University of Illinois at Urbana-Champaign, Illinois. 